\title{
Cytogenetic effect of lactobacillus acidophilus concentrated filtrate on albino mice bone marrow cells
}

\author{
التأثير الوراثي الخلوي لبكتريا \\ العظم للفئران البيض
}

\section{Ebtehal H. Al-Naimie}

\section{Muthanna A.S. Al-Mahdawii***}

Biotechnology Research Center / Al-Nahrain University

* Biotechnology Dept. / College of Science/ Al-Nahrain University

** Microbiology Dept. / College of Science/ Diyala University

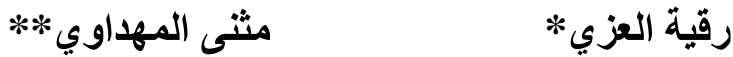

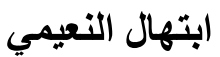

$$
\begin{aligned}
& \text { مركز بحوث التقنيات الاحيائية/جامعة النهرين } \\
& \text { * قسم التقانة الإحيائية/كلية العلوم/جاتئة التهاتة النهرين } \\
& \text { **قسم الأحياء ألدجهرية/كلية العلوم/جامعة ديالى الإلى }
\end{aligned}
$$

\section{Abstract}

This study deals with the cytogenetic effect of lactobacillus acidophilus concentrated filtrate on metaphase index of bone marrow cells in mice. Cyclophosphamide is a drug that is used primarily for treating several types of cancer. In order to work, cyclophosphamide first is converted by the liver into two chemicals, acrolein and phosphoramide. The results showed that lactobacillus acidophilus concentrated filtrate caused a significant increased in metaphase index in comparison with the negative control (distilled water) and positive controls (Cyclophosphamide) especially at high doses. The results of interaction study showed that pre- and posttreatment with lactobacillus acidophilus concentrated filtrate caused a significant increased in metaphase index of mice bone marrow cells.

تم فحص التأثيرات الوراثية الخلوية لمستخلصLactobacillus acidophilus من خلال قياس معامل الاتقسام

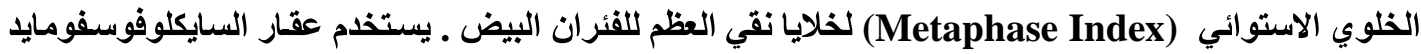

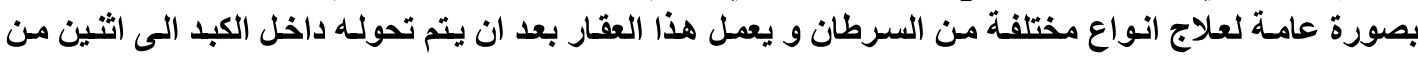

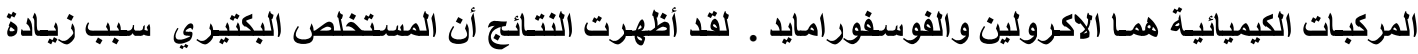

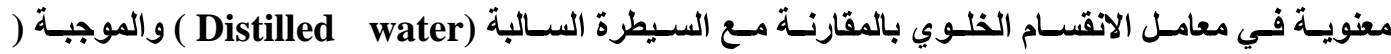

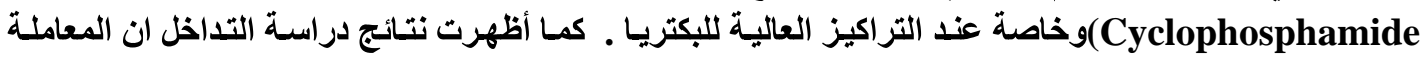

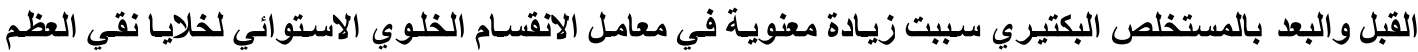




\section{Introduction}

Under domesticated conditions, stress factors cause deficiencies to occur which render the animal vulnerable to infection. Under these circumstances, supplementation with live microorganisms to repair the deficiencies in the composition of the gut micro flora can stimulate an immune response and restore the animals resistance to infection [1]. Various natural supplements have shown some promise for improving the effectiveness of conventional cancer therapy (specifically: chemotherapy and radiation) or reducing its side effects [2]. A primary therapy to cure a small percentage of malignancies is chemotherapy, it was used as adjuvant therapy to decrease the rate of relapse or improve the disease-free interval to palliate symptoms also the therapy aimed to prolong survival in some cases of incurable malignancies prior to surgery to reduce the size of tumor, rendering it more operable post surgery to decrease the risk of occult micromestaseses of tumor stem cells outside the primary field [3]. There are over sixty different drugs used in chemotherapy, most being specific to certain types of cancer, these drugs are often used in combination - having different mechanisms of action and metabolic pathways. Some of these chemotherapeutics agents are Cyclophosphamide, Ifosfamide, Chlorambucil, Melphalan, Busulphan which act as Alkylating Agents [4]. Mitotic index assay is defined as the ratio of the numbers of cells in a population undergoing mitosis to the total numbers of cells [5]. Therefore, by the employment of this assay the effect of different physical and chemical agents on the mitotic response can be detected, and studies have revealed that the mitotic index can be affected negatively or positively by chemicals, radiations, drugs and medicinal plants [6,7].

This study was aimed to evaluate the ability of concentrated filtrate of Lacidophilus in reducing the genotoxic effects of treatment with Cyclophosphomide, and the influence of concentrated filtrate of L. acidophilus-cyclophosphomide on metaphase index of bone marrow.

\section{Materials and methods:}

\section{Laboratory Animals}

Albino male mice (Mus musculus) were used to carry out the investigations of the present study. They were obtained from Biotechnology Research Center (Al-Nahrain University). Their range ages was 8-9 weeks, and their weight was 23-27 grams at the beginning of experiments. They were caged in the animal house of the supplier, in which the temperature was $23-26^{\circ} \mathrm{C}$, and light: dark periods of 10:14 hours/day. The animals had free excess to diet (standard pellets) and drinking water during all experiments.

\section{Experimental Design}

Three doses of Lactobacillus acidophilus concentrated filtrate experiment [13] were used to assess the cytogenetic effects of cell free extract of Lactobacillus acidophilus, and their modulating effects on the drug cyclophosphomide in albino male mice. Two stages were used in the evaluation.

\section{First Stage}

In this stage, the cytogenetic effects on mitotic index of three doses of Lactobacillus acidophilus concentrated filtrate and cyclophosphomide were investigated. The animals were divided into three groups: 
- Group I: treated with distilled water (negative controls $=8$ animals).

- Group II: treated with cyclophosphomide at a dose of $15 \mathrm{mg} / \mathrm{kg}$ (positive controls = 8 animals)

- Group III: treated with three doses of the Lactobacillus acidophilus concentrated filtrate $(250,500$ and $750 \mathrm{mg} / \mathrm{kg})(24$ animals).

The tested materials were given orally as a single dose $(0.1 \mathrm{ml})$ per day for 7 days. Then the mice were sacrificed in day 8 for laboratory assessments. The total numbers of mice in this stage were 40 animals.

\section{Second Stage}

In this stage, interactions (pre- and post-treatments) between the ideal dose of Lactobacillus acidophilus concentrated filtrate $(250 \mathrm{mg} / \mathrm{kg}$ ) and cyclophosphomide (15 $\mathrm{mg} / \mathrm{kg}$ ) (company leaflet) were carried out. The criterion of selection for the ideal dose was based on the approximation between the values of mitotic index in the animals treated with concentrated filtrate and negative controls.

- In pre-treatment interaction, the Lactobacillus acidophilus concentrated filtrate was given for 6 days $(250 \mathrm{mg} / \mathrm{kg}$ single dose/day), while cyclophosphomide was given (single dose/day) in day 7 , and then animals were sacrificed in day 8 for laboratory assessments. In both cases, the materials were given orally $(0.1 \mathrm{ml})$. The total number of mice in this interaction was 8 animals.

- In post-treatment interaction, the animals was given cyclophosphomide (single dose/day) on day one, while the Lactobacillus acidophilus concentrated filtrate was given in day 2 till day 7 (single dose/day), and then animals were sacrificed in day 8 for laboratory assessments. In both cases, the materials were given orally $(0.1 \mathrm{ml})$. The total number of mice in this interaction was 8 animals.

\section{Mitotic index}

The metaphase index was assessed on somatic cells obtained from the bone marrow of experimental animal mice, according to a pre-established method (8), which was based on the following steps:

1. The animal was injected intraperitoneally with $(0.25 \mathrm{ml})$ of colchicines solution with concentration of $(1 \mathrm{mg} / \mathrm{ml})$, and after two hours, the animal was sacrificed by cervical-dislocation.

2. The animal was dissected, and femur bone was removed and transferred to two Petri dishes containing $5 \mathrm{ml}$ of PBS.

3. The femur bone was cleaned from muscles and other tissues, and both ends were cut. Then, the bone marrow was obtained with PBS (5 ml) using disposable insulin syringe, and collected in a test tube.

4. The cell suspension of tube was gently pipette and centrifuged $(2000 \mathrm{rpm})$ for 5 minutes.

5. After discarding the supernatant, the cell deposit was suspended in $10 \mathrm{ml}$ of a warm $\left(37^{\circ} \mathrm{C}\right)$ hypotonic $\mathrm{KCl}(0.075 \mathrm{M})$, and incubated for 30 minutes in a water bath $\left(37^{\circ} \mathrm{C}\right)$, with shaking every 5 minutes.

6. The tube was centrifuged $(2000 \mathrm{rpm})$ for 5 minutes, and the supernatant was discarded. 
7. The cell deposit was slowly suspended in $5 \mathrm{ml}$ of cooled fixative $(4 ? \mathrm{C})$, and incubated for 30 minutes at $4^{\circ} \mathrm{C}$.

8. Step 7 was repeated, and the cell deposit was gently suspended in 1-2 $\mathrm{ml}$ of cooled fixative, to prepare a single cell suspension.

9. Few drops (4-5 drops) of the fixed cell suspension were dropped vertically from a height of about 3 feet on cleaned slides to give chance for nuclei and chromosomes to spread well.

10. The slides were air-dried, stained with Giemsa stain for 15 minutes, rinsed with distilled water, and left to dry at room temperature.

11. The slides were examined under oil immersion lens (100X), and at least 1000 cells (divided and non-divided cells) were scored. Then, the percentage of metaphase cells (metaphase index) was calculated according to the following equation:

$$
\text { Metaphase index }(\%)=\left(\frac{\text { Number of Metaphase Cells }}{\text { Total Count }}\right) \times 100
$$

\section{Results}

In the present study the metaphase index for bone marrow cells was estimated in which only cells at metaphase were scored figure (1) in sample of 1000 cells, while their percentage was given.

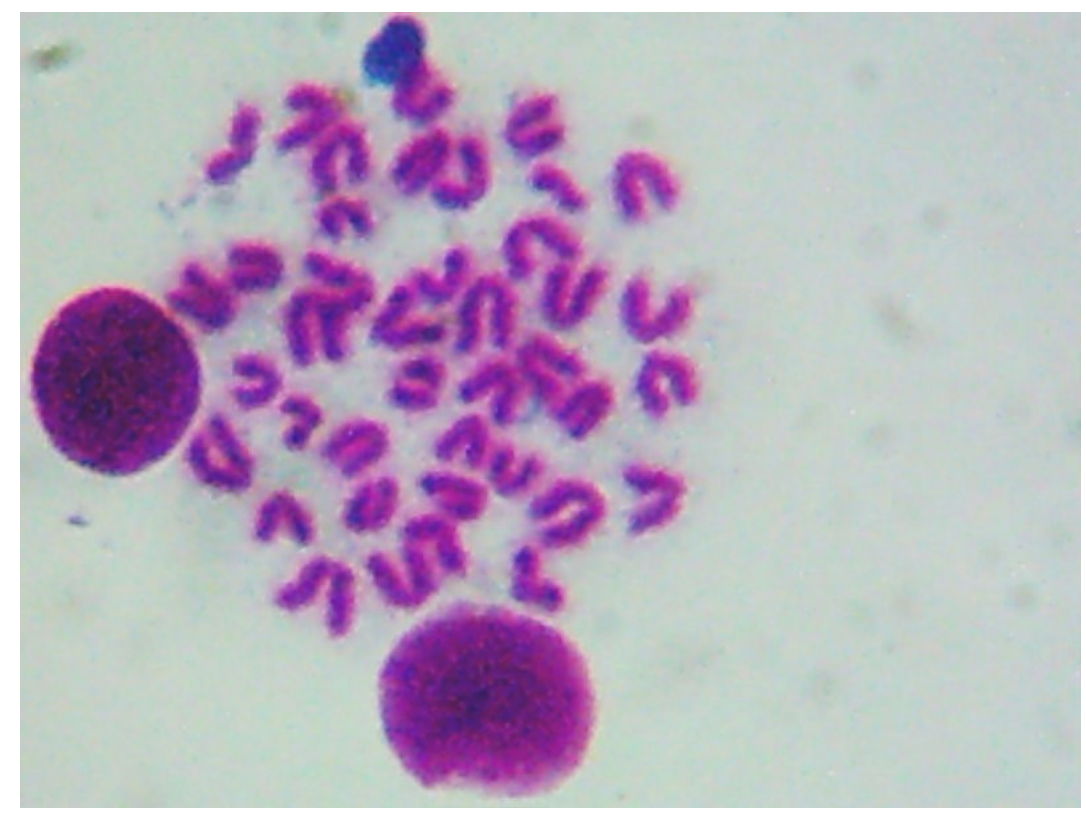

Figure ( 1) : A metaphase preparation from bone marrow of mouse treated with Lactobacillus acidophilus concentrated filtrate (100X).

\section{Bone marrow}

A treatment with cyclophosphomide caused a non significant reduction in the metaphase index $(2.41 \%)$ as compared to the negative control (2.96\%). In contrast, the differences were significant for all doses of concentrated filtrate of $L$. acidophilus as compared to the negative control $(7.30 \%, 3.98 \%$ and $4.80 \%$ vs. $2.41 \%)$ Table (1). 
Table (1): Metaphase index of bone marrow cells (mean \pm standard error) of albino male mice treated with Lactobacillus acidophilus concentrated filtrate, (negative controls) and (positive control).

\begin{tabular}{|c|c|c|c|c|c|}
\hline \multicolumn{2}{|l|}{ Groups } & $\begin{array}{l}\text { Dose } \\
(\mathrm{mg} / \mathrm{kg})\end{array}$ & $\begin{array}{l}\text { Mean } \quad \pm \\
\text { Standard } \\
\text { Error \% }\end{array}$ & $\begin{array}{l}\text { Treatment } \\
\text { Efficiency } \\
(\%)\end{array}$ & $\begin{array}{l}\text { Statistical } \\
\text { Evaluation }\end{array}$ \\
\hline \multicolumn{2}{|c|}{$\begin{array}{l}\text { Positive Control } \\
\text { (cyclophosphomide Drug) }\end{array}$} & 15 & $2.41 \pm 0.41$ & -18.44 & A \\
\hline \multicolumn{2}{|c|}{$\begin{array}{l}\text { Negative Control (Distilled } \\
\text { Water) }\end{array}$} & 0.00 & $2.96 \pm 0.21$ & & A \\
\hline \multirow{3}{*}{ 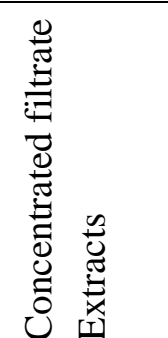 } & First dose & 250 & $7.30 \pm 0.82$ & 147.03 & B \\
\hline & Second dose & 500 & $3.98 \pm 0.30$ & 34.69 & $\mathrm{C}$ \\
\hline & Third dose & 750 & $4.80 \pm 0.41$ & 62.35 & $\mathrm{C}$ \\
\hline
\end{tabular}

Different letters in the same column: significant difference $(P \leq 0.05)$ between means.

Concentrated filtrate of Lactobacillus acidophilus - cyclophosphomide interactions

Two types of interactions (pre-and post- treatment) were carried out between the ideal dose of Lactobacillus acidophilus concentrated filtrate and cyclophosphomide to evaluate the role of the concentrated filtrate in modulating the cytological effect of the drug in albino male mice. The selection of ideal dose was based on the results of metaphase index of bone marrow as indicated above table (1).

\section{Metaphase Index of Bone Marrow cells}

The concentrated filtrate of Lactobacillus acidophilus was significantly effective in enhancing the metaphase index of bone marrow cells in the pre-treatment interaction as compared to the corresponding controls (2.41\%vs.1.62\%). Also, the post-treatment caused significant increased in the metaphase index as compared to the corresponding control (5.46\% vs. $3.18 \%)$ table (2). 
Table (2): Metaphase index of bone marrow cells in albino male mice after interactions (pre- and post-treatments) between the ideal dose (250 $\mathrm{mg} / \mathrm{kg}$ ) of concentrated filtrate of Lactobacillus acidophilus and cyclophosphamide drug.

\begin{tabular}{|c|c|c|c|c|}
\hline \multirow[b]{2}{*}{ Groups } & \multicolumn{2}{|c|}{$\begin{array}{c}\text { Mean } \pm \text { Standard Error } \\
(\%)\end{array}$} & \multicolumn{2}{|c|}{$\begin{array}{l}\text { Treatment Efficiency } \\
\qquad(\%)\end{array}$} \\
\hline & Pre-treatment & Post-treatment & $\begin{array}{c}\text { Pre- } \\
\text { treatment }\end{array}$ & $\begin{array}{l}\text { Post- } \\
\text { treatment }\end{array}$ \\
\hline $\begin{array}{c}\text { Control } 1 \text { (Distilled Water + } \\
\text { cyclophosphomide) }\end{array}$ & $1.62 \pm 0.09 \mathrm{a}$ & $3.18 \pm 0.18$ & & \\
\hline $\begin{array}{c}\text { Control } 2 \text { (concentrated filtrate+ } \\
\text { cyclophosphomide) }\end{array}$ & $2.41 \pm 0.01 \quad b$ & $5.46 \pm 0.045 \quad b$ & 48.8 & 43.3 \\
\hline
\end{tabular}

Different letters in the same column: significant difference $(P \leq 0.05)$ between means

\section{Discussion}

The beneficial activity of probiotics as show from the above result especially the increasing the mitotic index may be exerted through the immunomodulation of gut associated lymphoid tissue. The suggestion that commensally bacteria may have a role in induction of anti inflammatory signals, as tested in intestinal epithelial cell lines [9]. Several studies have reviewed the evidence for the suppression of carcinogenesis by Lactobacillus acidophilus $[10,11]$ based on research concerning anti mutagenic and anti carcinogenic activity. There is also evidence in humans that oral supplements of $L$. acidophilus reduce activities of fecal bacterial enzymes such as b- glucuronidase, nitroreductase and azoreductase that are involved in procarcinogen activation [10].

The active metabolite released by probiotic bacteria during intestinal transit may cross the intestinal layer to exert anti-inflammatory effects, and may explain the beneficial effects of probiotic bacteria as adjuvant [11].

Many researchers have studied the biological basis of the antitumor effect of dietary Lactobacillus acidophilus in various animal models for human cancer. The understanding of the suppression of antitumor activity has led to the conclusion that the Lactobacillus acidophilus could act by modulation of the immune response. However, the mechanisms are not the same for different types of tumor. In addition, therapeutic antitumor effect by Lactobacillus acidophilus differs as a function of dose, time of administration and the route chosen $[12,13]$. The mechanism by which probiotics exert their effects are largely unknown, but may involve stimulating immunomodulatery cells [14], it was found that production of protein (bacterocin) increasing the activity of the bacteria [15].

\section{References}

1. Perdigon,G; Fuller and Raya,R.(2001).Lactic acid bacteria and their effect on the immune system.Curr.Iss.Intestinal Microbiol.,2(1):27-42.

2. Kellof,G.;Sigman,C. and GreenWald,P.(1999).Cancer chemoprevention: Progress and Primose.Eur.J.cancer.35:1755-1762.

3. Labriola, D. and Livingston, R. (1999). Possible interactions between dietary antioxidants and chemotherapy. Oncology. 13: 1003-1012. 
4. Lissoni, P.; Barni, S. and Mandalà, B. (1999).Decreased toxicity and increased efficacy of cancer chemotherapy using the pineal hormone melatonin in metastatic solid tumour patients with poor clinical status. Eur. J. Cancer. 35:1688-1692.

5. Ghosh, B.B.; Talukder, G. and Shorama, A. (1991). Effect of culture media on spontaneous residence of mitotic index, chromosomal aberration, micronucleus counts, sister chromatid exchange and cell cycle. Kinetics in principle blood lymphocytes of male and female donars. Cytobios, 67: 71-75.

6. Ad'hiah,A.H.; Al-Kashaly,S.S. and Abbas,T.A.A. (2002). Group A streptococcus (Streptococcus piygoenes) and the mitotic activity of lymphoid organs in albino mice. The Eight Scientific Conference of the Technical Education Committee, PP. 302-208.

7. Ad'hiah,A.H.; Sayhood, Y.D. and Shubber, E.K. (2004). Inhibiting the hematological and cytogenetic effects of tamoxifen by alcoholic extract of garlic (Allium sativum). Nucleus, 47: 10-16.

8. Allen, J.W; Shuller,C.F.; Mendes,R.W. and Latt,S.A.(1977). A simplified technique for in vivo analysis of sister chromatid exchange using 5-bromo-deoxy uridine tablets. Cytogenetics and Cell Genetic, 18: 231-237.

9. Neish,A.S.;Gewirtz,A.T. and Zeng,H.(2000).Prokaryotic regulation of epithelial responses by inhibition of Ikappa B-alpha ubiquitination.Science, 289:1560-63.

10. Nadathur,S.; Gould,S. and Bakalinsky,A. (1994). Antimutagenicity of fermented milk. J. Dairy Sci. 77: 3287-3295.

11. Heyman,M. and Menard,S.(2002).Probiotic microorganisms:how they affect intestinal pathophysiology.Cell Mol.Life Sci.,59:1151-56

12. Gill, H.S.; Rutherfurd, K.J. and Cross,M.L. (2001). Dietary probiotic supplementation enhances natural killer cell activity in the elderly: an investigation of age-related immunological changes. J. Clin. Immunol. 21:264-71.

13. AL-Yas, M.Ch. (2006). Evaluation of Different Methods for detection of Helicobacter pylori Isolated from Human and the Effect of Probiotics on its Growth. A Ph.D thesis submitted to the college of science Al-Nahrain University.

14. Noback,S.;Johasson,M.L;Molin,G.(2000).Alteration bloating intestinal micro flora is associated with reduction in obominate and pain in patients with irritable bowel syndrome.Am.J.Gastroentero.95:1231-1238.

15. Garver,K.I. and Muriana,P.M.(1994).Purification and amino acid sequence curvaticin FS47, a heat stable bacteriocin produced by Lactobacillus curvatus FS47Appl.Environ .Microbiol..60:2191-2195. 